\title{
Komunitas Fitoplankton Perairan Pantai Utara, Timur, Dan Selatan Pulau Lombok
}

\author{
Oleh: \\ Lalu Japa $^{(1)}$ dan Khairuddin ${ }^{(2)}$ \\ (1) dan (2) Program Studi Pendidikan Biologi FKIP Universitas Mataram
}

\begin{abstract}
ABSTRAK
Perairan pantai menyediakan sumber daya alam yang melimpah dan potensial untuk dimanfaatkan secara ekonomi. Tidak sedikit kegiatan pemanfaatan ekosistem pantai yang disertai dengan dokumen pengelolaan. Tolok ukur kualitas perairan yang banyak dipakai dan dilaporkan adalah komunitas fitoplankton. Untuk itu, survey ini dilakukan pada 3 stasiun di kawasan pemanfaatan ekosistem pantai untuk kegiatan budidaya kerang mutiara. Empat titik sampling ditetapkan pada masing-masing stasiun. $50 \mathrm{ml}$ sampel air laut diambil pada setiap titik sampling menggunakan jaring plankton dengan mata jaring berukuran $20 \mu \mathrm{m}$. Perairan pantai utara dan timur pulau Lombok didominasi oleh Bacteriastrum delicatulum dan pantai selatan pulau Lombok didominasi oleh Chaetoceros affinis. Secara umum, ketiga titik sampling penelitian ini didominasi oleh spesies dari genus Chaetoceros. Tetapi Bacteriastrum delicatulum adalah jenis yang paling dominan dan melimpah di ketiga lokasi sampling. Indeks diversitas spesies ketiga perairan pantai pulau Lombok tersebut termasuk kategori sedang.
\end{abstract}

Kata kunci: Komunitas, Fitoplankton, Perairan Pantai, Ekosistem

\section{PHYOPLANKTON COMMUNITY OF NORTH, EAST, AND SOUTH LOMBOK ISLAND COASTAL WATERS}

\begin{abstract}
Coastal waters providing numerous diversity of flora and fauna since the area is a suitable habitat for many flora and fauna species and have some high economic potential uses. The flora and fauna than have economical benefits. Community of phytoplankton is commonly recorded and studied for biological indicator of aquatic ecosystem sustainability. Four sampling sites of each three station (north, east, and south) of Lombok coastal waters were absorbed for phytoplankton community. Tweleve of $50 \mathrm{ml}$ bottles coastal waters samples were taken using a nylon plankton net of $20 \mu \mathrm{m}$ mesh size. The north and east coastal waters of Lombok were dominated by Bacteriastrum delicatulum and the south coastal water of Lombok was dominated by Chaetoceros affinis. In general the coastal waters of Lombok were dominated by species of the genus of Chaetoceros. However, diatom Bacteriastrum delicatulum was the most commonly found and has the highest density in all sampling sites.Species diversity index of phytoplankton in all three sampling station of this study was intermediate category
\end{abstract}

Key woods: Community, Phytoplankton, Coastal Water, Ecosystem

\section{PENDAHULUAN}

$\mathrm{W}$

ilayah Negara Kesatuan

Republik Indonesia memiliki garis pantai sekitar $81.000 \mathrm{~km}$ panjangnya (Resosoedarmo dkk., 1992; Dahuri, 2000), dengan luas perairan lautnya mencapai $67 \%$ dari total wilayah Indonesia (Noor, 2000). Kawasan perairan 
laut yang sedemikian luasnya ini merupakan potensi sumber daya alam yang tak ternilai harganya, tetapi sekaligus menciptakan tantangan yang sangat besar bagi pengelolaannya.

Potensi sumberdaya alam hayati suatu kawasan atau eksosistem perairan sangat ditentukan oleh produktivitas primer plankton (zooplankton dan fitoplankton). Plankton adalah organisme yang hidup melayang pada ekosistem perairan dengan aktivitas gerakannya mengikuti arus atau aliran yang dalam rantai pakan (foodchain) termasuk kelompok yang paling rendah tingkatannya. Organisme plankton yang memiliki sifat seperti tumbuhan termasuk kelompok fitoplankton (phytoplankton) yang umumnya berperan sebagai produsen, yang memiliki sifat seperti binatang termasuk kelompok zooplankton yang berperan sebagai konsumen. Bahkan terdapat juga plankton yang memiliki kedua sifat tersebut, seperti Euglena yang memiliki chlorophyl (zat hijau daun), namun aktivitasnya seperti binatang di dalam air.

Zooplankton adalah organisme konsumen pertama dan utama sangat bergantung pada fitoplankton sebagai produsen pertama pada ekosistem perairan. Arinardi (1978) menyimpulan walaupun jumlah fitoplankton sangat tinggi tetapi jumlah zooplankton bisa sangat rendah dan sebaliknya. Ini berarti, bahwa komunitas zooplankton dan fitoplankton dipernagruhi oleh banyak faktor, tidak hanya faktor biologi tetapi juga faktor kimia dan fisika perairan. Selanjutnya, fitoplankton sebagai organisme uniseluler air sangat peka dengan perubahan ekosistem perairan, yang tercermin dari kualitas airnya. Keberadaan komunitas fitoplankton juga merupakan kelompok organisme perairan yang paling banyak dilaporkan sebagai tolak ukur dalam mengontrol kualitas dan produktivitas suatu perairan.
Kemelimpahan fitoplankton di suatu perairan menggambarkan produktivitas primer ekosistem perairan tersebut. Fitoplankton sebagai komponen dasar jaring-jaring makanan ekosistem perairan merupakan sumber makanan utama organisme periaran terutama zooplankton yang kemudian dimakan oleh ikan-ikan kecil. Ikan-ikan kecil ini selanjutnya akan dimangsa oleh ikan-ikan yang lebih besar dan seterusnya sampai kepada predator lainnya, sehingga memungkinkan terjadinya aliran energi dan materi sampai ke jenjang profit yang lebih tinggi, bahkan sampai ke puncak profit, manusia. Bisa dibanyangkan, bahwa kehilangan fitoplankton sampai $5 \quad \%$ dapat menyebabkan menurunnya produksi ikan sampai 70.000 ton setiap tahun (Harder et al., 1995). Berkenaan dengan itu, dan managemen qualitas air merupakan kebijakan penting untuk aspek lingkungan dan sumber alam (Hall dan Smol, 1999), yang memerlukan perhatian secara khusus agar dapat menentukan kebijakan pengelolaan yang optimal untuk kesejahteraan dengan prinsip berkelanjutan dan ramah lingkungan.

Sampai saat ini tingkat aspirasi masyarakat, tak terkecuali masyarakat intelektual terhadap keberadaan kelompok organisme ini di tengah-tengah kehidupan masih sangat rendah, sehingga organisme yang tak kasap mata ini nyaris tak pernah dijamah dalam skop pengertian ilmiah. Penelitian mengenai hubungan antara zooplankton dan fitoplankton sangat terbatas khususnya di Indonesia, dan tidak pernah dilakukan di perairan pulau Lombok. Komunitas fitoplankton perairan Indonesia dilaporkan pertama kali oleh Allen dan Cupp (1935) untuk sebagian kecil daerah perairan Jawa, Sumatera dan Kalimantan dan Hustedt (1939) untuk kawasan yang sama ditambah Bali. Penelitian terbaru untuk satu titik di pulau 
Lombok dilaporkan oleh Japa (2000). Tidak menutup kemungkinan, sebagaimana di negara-negara di belahan bumi lainnya, spesies-spesies yang potensial beracun dan mengalami blooming sangat mungkin dijumpai di perairan Indonesia, termasuk Lombok.

\section{METODE}

Alat dan bahan yang dipergunakan dalam studi ini meliputi: jaring plankton, mikropipet, mikroskop, gelas benda dan gelas penutup, botol sampel, formalin dan kertas tissue.

Sampel air laut sebanyak $50 \mathrm{ml}$ (volume botol jaring plankton) diambil menggunakan jaring plankton dengan ukuran matajaring $20 \mu \mathrm{m}$. Pada setiap lokasi sampling sampel air laut diambil pada 3 titik (Teluk Nare, Lombok bagian utara; Labuhan Pandan, Lombok bagian timur; dan Tanjung Ringgit, Lombok Bbagian selatan), dengan cara menenggelamkan jaring sampai kedalaman $7 \mathrm{~m}$ kemudian jaring ditarik sampai ke permukaan. Sampel diawet dengan formalin pada konsentrasi pengawetan $4 \%$. Sampel diamati di Laboratorium Biologi PMIPA FKIP Unram menggunakan mikroskop merek Olympus pada perbesaran 10 x 10 , dan 10 x 20 . Identifikasi jenis dilakukan secara morfologi (Hall dan Smol, 1999) dan mengacu pada buku-buku yang ditulis oleh Labour (1930), Allen dan Cupp (1935), Davis (1955); Simonsen, (1974); Belcher dan Swale, (1976); Taylor, (1976); Vinyard, (1979); Navarro, (1982); Yamaji (1984); dan Hernandez-Becerril, (1996).

Analisis data komunitas fitoplankton dan zooplankton dititik beratkan pada penghitungan kemelimpahan (D), nilai penting (NP), dan indeks keanekaragaman jenis $\left(\mathrm{H}^{\prime}\right)$. Jenis dengan nilai penting paling tinggi menunjukkan, bahwa jenis tersebut relatif paling melimpah di komunitas tersebut (Michael, 1984), Kemelimpahan setiap jenis fitoplankton ditentukan berdasarkan jumlah individu per liter air. Perhitungan kemelimpahan setiap jenis fitoplankton dalam 1 liter air menggunakan rumus dari Romimuhtarto dan Juwana (2001). Nilai penting setiap jenis fitoplankton dihitung dari penjunlahan nilai kemelimpahan dan frekwensi relative setiap jenis. Indeks keanekaragaman jenis fitoplankton ditentukan berdasarkan "Indeks ShannonWienner (H')" dengan rumus dari Cox (1976), Romimuhtarto dan Juwana (2001), dan Barus (2001).

\section{HASIL DAN PEMBAHASAN}

Distribusi dan daftar spesies fitoplankton perairan Utara, Timur, dan Selatan Pulau Lombok disajikan pada Tabel 1. Dari 83 spesies komunitas fitoplankton yang berhasil diidentifikasi dalam penelitian ini, 70 spesies merupakan anggota dari famili Bacillariophyceae, dan hanya 13 spesies anggota dari famili Dinophyceae. Pada beberapa penelitian sebelumnya, yang dilakukan di sekitar perairan pantai pulau Lombok juga diperoleh hasil, bahwa anggota Bacillariophyceae selalu mendominasi Dinophyceae, misalnya: Japa (2000) di perairan pelabuhan Lembar, Lombok Barat; Feranita (2002), di perairan pelabuhan Kayangan, Lombok Timur; Japa dan Suripto (2003) di perairan Sambelia Lombok Timur; dan Sumarni (2003) di perairan Kerta Sari Taliwang, Sumbawa.

Pada perairan di sekitar budidaya kerang mutiara di Teluk Nare, indeks diversitas fitoplankton air laut termasuk kategori sedang $\left(\mathrm{H}^{\prime}=2,983\right)$, Komunitas fitoplankton perairan Teluk Nare didominasi oleh Bacteriastrum delicatulum $(\mathrm{NP}=18,519 \%)$ dengan densitas $45 \mathrm{ind} / \mathrm{L}$, disusul berturut-turut oleh diatom jenis Chaetoceros liciniosum $(\mathrm{NP}=15,259 \%)$, 
Chaetoceros diversum $(\mathrm{NP}=13,481 \%)$, Pseudonitzschia spp, $(\mathrm{NP}=12,840)$, dan Thalassionema nitzschicoides (NP $=12,148 \%$ ), masing-masing dengan densitas 35,1 ind/L, 29,7 ind/L, 31,5 ind/L dan 25,65 ind/L. Bacteriastrum delicatulum juga merupakan jenis diatom yang melimpah dan dominan di perairan Labuhan Pandan Lombok Timur (NP = $13,667 \%$ ) dengan densitas 35,1 ind/L, walaupun nilai kemelimpahan dan dominasinya lebih rendah disbanding dengan di perairan Teluk Nare. Bacteriastrum delicatulum adalah jenis yang paling dominan dan melimpah di ketiga lokasi sampling dalam studi ini. Jenis lain yang juga cukup dominan di perairan Labuhan Pandan adalah Chaetoceros lorenzianum dengan nilai penting sebesar $10,850 \%$ dan densitas (D) sebesar 23,850 ind/L dan Bacteriastrum varians $(\mathrm{NP}=10,046 \%$ dan $\mathrm{D}=23,400)$. Indeks keanekaragaman jenis fitoplankton di perairan Labuhan Pandang sebesar 3,247 (keanekaragaman kategori sedang). Selanjutnya pada perairan Tanjung Ringgit, komunitas fitoplankton didominasi oleh Chaetoceros affinis ( $\mathrm{D}=16,200 \mathrm{ind} / \mathrm{L}$ dan $\mathrm{NP}=16,778 \%$ ), Bacteriastrum delicatulum dan Chaetoceros curvisetus adalah dua jenis yang memiliki kemelimpahan dan dominasi tertinggi kedua di perairan Tanjung Ringgit (masing-masing D
$=12,150 \mathrm{ind} / \mathrm{L}$ dan NP $=14,823 \%$. Indeks keanekaragaman jenis fitoplankton di perairan Tanjung Ringgit juga termasuk kategori sedang $\left(\mathrm{H}^{\prime}=3,118\right)$. Nilai indeks keanekaragaman jenis (H') baik fitoplankton maupun zooplankton perairan suaka perikanan gili Ranggo teluk Serewe tergolong dalam kategori tinggi. Barus (2001) membagi kisaran nilai indeks keanekaragaman menjadi tiga kategori: a). Keanekaragaman rendah $\left(0<\mathrm{H}^{\prime}<2,302\right)$, b). Keanekaragaman sedang $\left(2,302<\mathrm{H}^{\prime}<\right.$ 6,907), dan c). Kenanekaragaman tinggi (H'> 6,907).

Secara umum dilihat dari jumlah jenis, maka ketiga titik sampling didominasi oleh genus Chaetoceros, masing-masing 11, 9, dan 7 jenis berturut-turut pada Teluk Nare, Labuhan Pandan dan Tanjung Ringgit. Diatom Chaetoceros adalah komponen fitoplankton laut yang melimpah, tetapi karena jumlah spesiesnya yang sangat banyak maka rumit diidentifikasi (Hernandez-Becerril, 1996). Komunitas fitoplankton perairan suaka perikanan gili Ranggo teluk Serewe Lombok Timur juga didominasi oleh genus Chaetoceros dengan lebih dari 19 spesies. Genus Chaetoceros juga diidentifikasi mendominasi jenis yang lain di perairan Lembar (Japa, 2000), di perairan Kerta Sari Sumbawa (Sumarni, 2003).

Tabel 1. Spesies dan Distribusi Fitoplankton Di Perairan Pantai Utara, Timur, dan Selatan Pulau Lombok

\begin{tabular}{|c|c|c|c|c|c|c|c|c|c|c|}
\hline \multirow[t]{2}{*}{ No. } & \multirow[t]{2}{*}{ Nama Spesies } & \multicolumn{3}{|c|}{ Teluk Nare } & \multicolumn{3}{|c|}{$\begin{array}{l}\text { Labuhan } \\
\text { Pandan }\end{array}$} & \multicolumn{3}{|c|}{$\begin{array}{l}\text { Tanjung } \\
\text { Ringgit }\end{array}$} \\
\hline & & 1 & 2 & 3 & 1 & 2 & 3 & 1 & 2 & 3 \\
\hline & Amphipora gigantea & & & & & & + & & & \\
\hline 2. & Amphora decussata & & & & + & & & & & \\
\hline & A. hyaline & + & & & & & + & & & + \\
\hline & A. laevis & & + & & + & + & + & + & & + \\
\hline & A. lineolata & & & + & + & + & + & & & \\
\hline & A. quadrata & & & & & & & & & + \\
\hline
\end{tabular}


7. Bacteriastrum delicatulum

8. B. elongatum

9. B. varians

10. Ceratium biceps

11. C. pulchellum

12. Chaetoceros affine

13. C. atlanticum

14. C. curvisetus

15. C. debile

16. C. decipiens

17. C. didymis

18. C. distans

19. C. diversum

20. C. laciniosum

21. C. lorenzianum

22. C. mesanense

23. C. lauderi

24. C. mitra

25. C. pseudocrinitum

26. C. seriacanthum

27. Climacosphenia moniligera

28. Codonellopsis americana

29. Corethron hystrix

30. Coscinodiscus nodulifer

31. Coscinodiscus spp.

32. Dactyliosolen antarcticus

33. Diploneis crabro

34. D. splendid

35. Dictyocha fibula

36. Eucampia cornuta

37. Globigerinella digitata

38. Globigerinella sp.

39. Gomphonema exignum

40. Gymnodinium splendens

41. Hemiaulus hauckii

42. Leptocylindricus danicus

43. Leptontinnus bottnicus

44. L. simplex

45. Licmophora abbreviata

46. Navicula cancellata

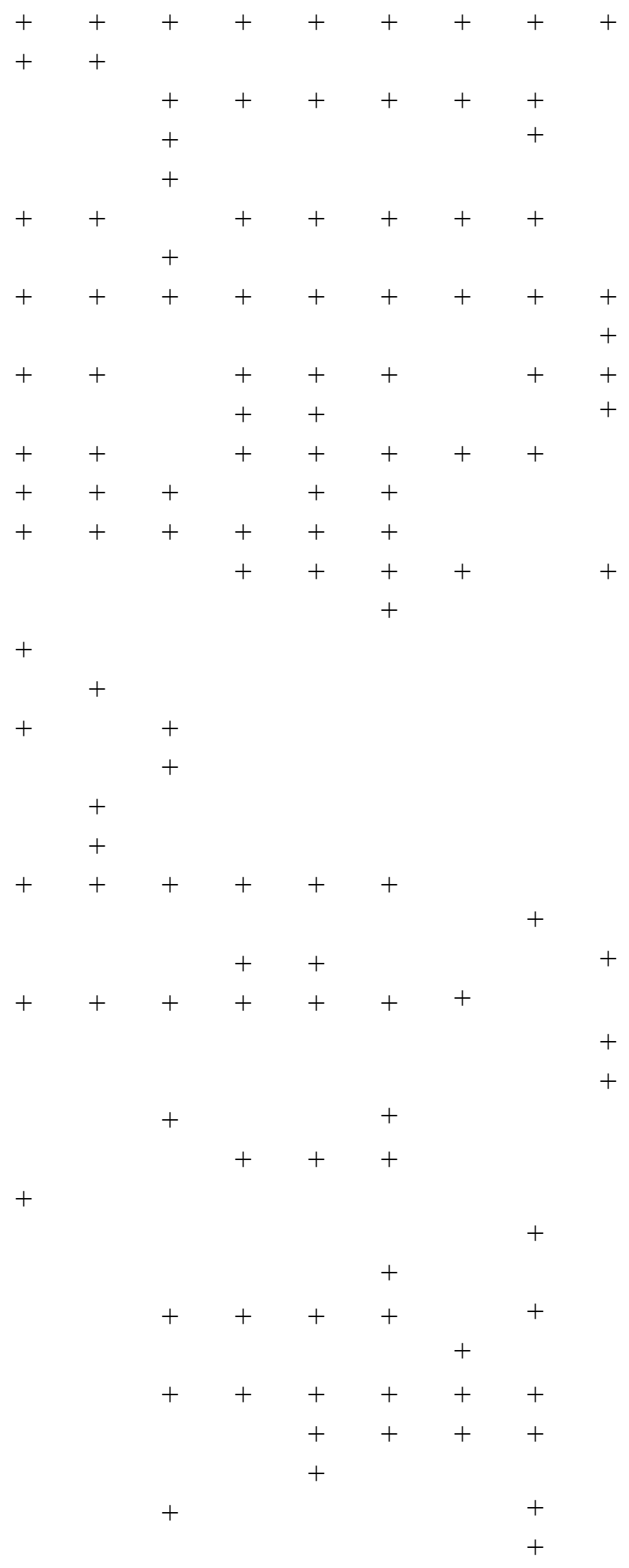


47. N. distans

48. N. cancellata

49. N. elegans

50. N. salinarum

51. Navicula $\mathrm{sp}$.

52. Nitzschia lanceolata

53. N. longissima

54. N. pungene

55. Nitzschia spp.

56. Palagothrix clevei

57. Piridinium quinquecorne

58. Pleurosigma sp.

59. Protoperidinium ovum

60. Pediastrum trochoidea

61. Piridinium pellucidum

62. Piridinium quinquecorne

63. Protoperidinium majus

64. P. ovum

65. Prorocentrum balticum

66. P. minimum

67. P. triestinum

68. Protoperidinium oceanicum

69. Pseudonitzschia spp.

70. Rabdinella striata

71. Rhizosolenia alata

72. R. delicatula

73. R. fragillima

74. R. setigera

75. R. stolterfothii

76. Skeletonema costatum

77. Surirella cuneata

78. Thalassionema nitzschicoides

79. Thalassiosira oestrupii

80. Thalassiotrix frauenfeldii

81. Thalassiotrix sp.

82. Triceratium reticulum

83. Trethomphalus bulloides

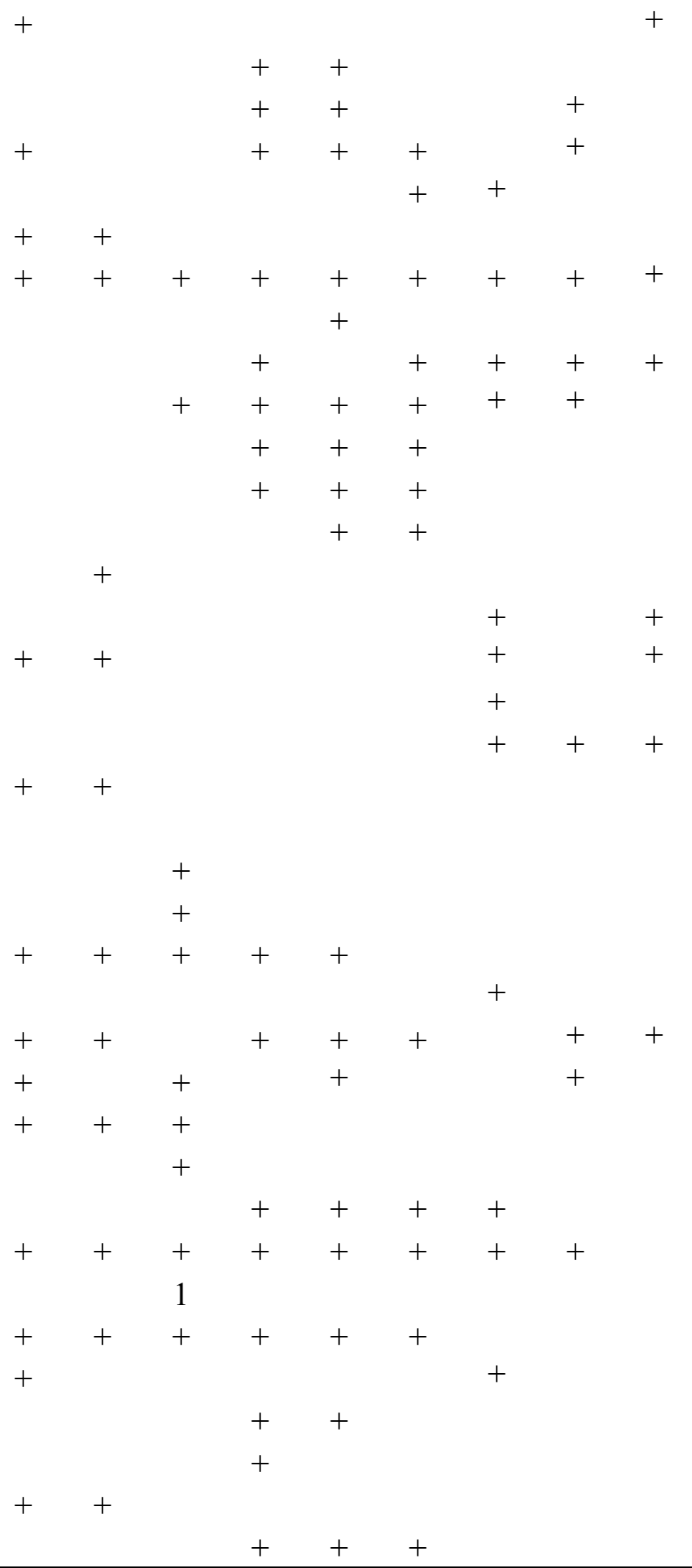

*Data primer, 2013 


\section{SIMPULAN}

Dari 83 spesies komunitas fitoplankton yang teridentifikasi dalam penelitian ini, 70 spesies merupakan anggota dari famili Bacillariophyceae, dan hanya 13 spesies anggota dari famili Dinophyceae. Komunitas fitoplankton perairan Teluk Nare Lombok Utara dan perairan Labuhan Pandan Lombok Timur didominasi oleh Bacteriastrum delicatulum, sedangkan komunitas fitoplankton perairan Tanjung Ringgit Lombok Timur, didominasi oleh Chaetoceros affinis. Indeks keanekaragaman spesies fitoplankton di perairan Teluk Nare, Labuhan Pandan dan di perairan Tanjung Ringgit termasuk kategori sedang. Dilihat dari jumlah spesies, ketiga titik sampling didominasi oleh spesies dari genus Chaetoceros, masing-masing 11, 9, dan 7 berturut-turut pada Teluk Nare, Labuhan Pandan dan Tanjung Ringgit.

\section{DAFTAR PUSTAKA}

Allen. W.E.. and E.E. Cupp. 1935. Plankton Diatoms of the Java Sea. Annales $d u$ Jardin Botanique de Buitenzorg. 44: 101-174.

Arinardi, O.H., 1978, Hubungan antara Kuantitas Fitoplankton dan Zooplankton di Perairan Sebelah Utara Gugus Pulau Pari Kepulauan Seribu, Oseanologi di Indonesia, 11: 73-85.

Barus. I.T.A.. 2001. Pengantar Limnologi. Direktorat Pembinaan Penelitian dan Pengabdian pada Masyarakat. Direktorat Jenderal Pendidikan Tinggi. Jakarta.

Belcher. J.H.. and E.M.F. Swale. 1976. A Beginner's Guide to Freshwater Algae. Institude of Terrestrial Ecology Natural Environmental Research Council. Cambridge. London.

Cox. G.W.. 1976. Laboratory Manual of General Ecology. W.M.C. Brown Co. Publisher. Iowa.
Dahuri, R., 2000, Kebijaksanaan Pengelolaan Sumberdaya Kelautan (Pesisir, Laut dan Pulau-Pulau Kecil), Makalah Konggres dan Seminar Kelautan Nasional KTI III, Lombok.

Davis. C.C.. 1955. The Marine and Freshwater Plankton. Michigan State University Press. Chicago.

Feranita, 2002, Evaluasi Kandungan Nitrat, Fosfat dan Kelimpahan Fitoplankton di Perairan Pelabuhan Kayangan Lombok Timur, Skripsi, Prog. S1 Pend. Biologi, FKIP Universitas Mataram.

Hall. R.I. and J.P. Smol. 1999. Diatoms as Indicators of Lake Eutrophication. di dalam E.F. Stoermer dan J.P. Smol (Editor). The Diatoms: Applications for the Environmental and Earth Sciences. Cambride University Press. United Kingdom.

Harder. D.P.. R.C. Worrest. H.D. Kumar. and R.C. Smith. 1995. Effects of Increased Solar Ultraviolet Radiation on Aquatic Ecosystems. Ambio. 24(3): 174-180.

Hernandez-Becerril. D.U.. 1996. A Morphological Study of Chaetoceros Species (Bacillariophyta) from the Plankton of the Pacific Ocean of Mexico. Bull. Nat. Hist. Mus. Lond. (Bot.). 26(1): 1-73.

Hustedt, F., 1939, Systematic and Ecological Investigation of the Diatom Flora of Java, Bali, and Sumatra, Archive Für Hydrobiolgie, Suppl. 15: 131-177, 16: 1-155, 187-295, and 393506.

Japa, L., 2000, Seasonal Succession of Phytoplankton Communities in Lombok Indonesian Coastal Waters, with Emphasis on Species of the Diatom Genera Pseudo-nitzshia and Thalassiosira, Thesis, Program Master, Universitas Tasmania.

Japa, L., dan Suripto, 2003, Inventarisasi Spesies Fitoplankton di Kawasan 
Perairan Budidaya Kerang Mutiara Dadap Sambelia Lombok Timur, Laporan Penelitian, Universitas Mataram, Mataram.

Lebour, M.V.. 1930. The Planktonic Diatoms of Northern Seas. Adlard and Son. Limited. London.

Michael, P., 1984, Ecology Methods for Field and Laboratory Investigations, Tata McGraw-Hill Publ. Co. Ltd., Toronto.

Navarro. J.N.. 1982. A Survey of the Marine Diatoms of Puerto Rico III.

Suborder Biddulphiineae: Family Chaetoceraceae. Botanica Marina. 25: 305-319.

Noor, A., 2000, Program Buginesia (Upaya Mengisi Matriks Pengetahuan Kelautan Indonesia) Dan Gagasan Pengembangan Riset Kelautan KTI, Makalah Konggres dan Seminar Kelautan Nasional KTI III, Lombok.

Resosoedarmo, R.S., K. Kartawinata dan A. Soegiarto, 1992, Pengantar Ekologi, Remaja Rosdakarya, Bandung.

Romimuhtarto. K. dan S. Juwana. 2001. Biologi Laut Ilmu Pengetahuan tentang Biota Laut. Djambatan. Jakarta.

Simonsen. R.. 1974. The Diatom Plankton of the Indian Ocean Expedition of R/V 'Meteor" 1964-1965. "Meteor" Forsch.-Ergebnisse. Berlin Stuttgart. 19(D): 1-107.

Sumarni, 2003, Keanekaragaman Jenis dan Kemelimpahan Bacillariophyta (Diatom) di Perairan Pantai Kerta Sari Taliwang Sumbawa, Skripsi, Prog. S1 Pend. Biologi, FKIP Universitas Mataram.

Taylor. F.J.R.. 1976. Dinoflagellates from the International Indian Ocean Expedition: A Report on Material Collected by the R.V. "Anton Bruun" 1963-1964. Stuttgart. E. Schweizerbart'sche Verlagsbuchhandlung (Nagele $u$ Obermiller).

Vinyard. W.C.. 1979. Diatoms of North America. Mad River Press. Inc.. California.

Yamaji. I.. 1984. Illustrations of The Marine Plankton of Japan. $3^{\text {rd }}$. Eddition. Hoikusha Publishing Co.. Ltd.. Japan. 